\title{
LIDAR OBSERVATION OF TROPOPAUSE OZONE PROFILES IN THE EQUATORIAL REGION
}

\author{
Yasukuni Shibata*, Chikao Nagasawa, Makoto Abo \\ Tokyo Metropolitan University, 6-6 Asahigaoka, Hino, Tokyo 191-0065, Japan \\ *Email:sibata@tmu.ac.jp
}

\begin{abstract}
Tropospheric ozone in the tropics zone is significant in terms of the oxidizing efficiency and greenhouse effect. However, in the upper troposphere, the ozone budget in the tropics has not been fully understood yet because of the sparsity of the range-resolved observations of vertical ozone concentration profiles. A DIAL (differential absorption lidar) system for vertical ozone profiles have been installed in the equatorial tropopause region over Kototabang, Indonesia (100.3E, 0.2S). We have observed large ozone enhancement in the upper troposphere, altitude of $13-17 \mathrm{~km}$, concurring with a zonal wind oscillation associated with the equatorial Kelvin wave around the tropopause at equatorial region.
\end{abstract}

\section{INTRODUCTION}

Recently, the significance of tropospheric ozone in the tropics has been recognized in terms of the oxidizing efficiency and greenhouse effect, and various efforts have been made to investigate its spatial distribution and temporal variation. However, especially in the upper troposphere, the equatorial ozone has not been fully understood yet because of the lack of the ground-based and longterm observations. Some papers of the equatorial ozonesonde observation report that a phenomenon of large ozone enhancement in the upper troposphere, altitudes of $12-16 \mathrm{~km}$, sometimes occurred [1,2]. Fujiwara et al. reports related to the equatorial Kelvin wave around the tropopause and the Madden-Julian oscillation (MJO) in the troposphere. The downward motion associated with the Kelvin wave and the MJO transported the stratospheric ozone into the troposphere, and the air mixing due to the Kelvin wave breaking at the tropopause also caused stratosphere-troposphere exchange.

We have constructed the lidar facility for survey of atmospheric structure over troposphere, stratosphere, mesosphere and low thermosphere over Kototabang, Indonesia in the equatorial region [3]. The lidar observations started from 2004, and routine observations of clouds and aerosol in the troposphere and stratosphere are continued now. We installed a DIAL (differential absorption lidar) system for high-resolution measurements of vertical ozone profiles in the equatorial tropopause region over Kototabang, Indonesia in 2014. This ozone lidar is possible to investigate the phenomenon of increasing ozone concentration of the equatorial upper troposphere in detail.

\section{OZONE DIAL SYSTEM}

We have installed DIAL system for highresolution measurements of vertical ozone profiles in the equatorial tropopause region over Kototabang. There were many ozone DIAL systems in the world, but their systems are almost optimized for stratospheric ozone layer measurement or tropospheric ozone measurement $[4,5]$. Because of deep ozone absorption in the UV region, the wavelength selection is important [6]. Over the equatorial region, the tropopause height is almost $17 \mathrm{~km}$. So we use $314 \mathrm{~nm}$ for online and $355 \mathrm{~nm}$ for off-line.

A schematic diagram of the integrated DIAL system is shown in Fig. 1. The radiation source of the lidar was a Q-switched frequency-tripled $\mathrm{Nd}$ :YAG laser $(355 \mathrm{~nm})$ with a $35 \mathrm{~mJ}$ output energy and a $10 \mathrm{~Hz}$ repetition rate. The dye laser consisted of a dual-wavelength generator. In case of the ozone measurements, the dye laser provided an on-line wavelength of $314 \mathrm{~nm}$ with a $4 \mathrm{~mJ}$ output energy. A harmonic generator equipped with a BBO crystal is used. The backscattered radiation from the atmosphere is collected by a 45 $\mathrm{cm}$ diameter telescope and a dichroic mirror divide the optical signal into two channels (for $314 \mathrm{~nm}$ and $355 \mathrm{~nm}$ ). The field of view of the receiving telescope is $2 \mathrm{mrad}$, and the distance between the optical axes of the telescope and the radiation beam is $2.5 \mathrm{~m}$. 
The DIAL system was achieved successfully test observation of $\mathrm{O} 3$ concentration profiles around equatorial troposphere with integration time of 6 hours and range resolution of $450 \mathrm{~m}$ on June 19, 2014. Because of the high frequency of occurrence of equatorial cirrus cloud, we need enough integration time for the observation ozone concentration over the tropopause. Fig. 2 shows the ozone concentration profile and radiosonde temperature profile. The radiosonde launched at the Tabing airport, Padang (100.2E, 0.5S) approximately $90 \mathrm{~km}$ from the lidar site. A large ozone enhancement in the upper troposphere, altitude of $13-17 \mathrm{~km}$, was observed. Fig. 3 shows the variation of temperature profile at Padang in June, 2014. The tropopause height moved downward from $18 \mathrm{~km}$ on June 7 to $16 \mathrm{~km}$ on June 17. After June 18, the tropopause height jumped up to $18 \mathrm{~km}$ concurring with a zonal wind oscillation associated with the equatorial Kelvin wave around the tropopause at equatorial region. Therefore, the downward motion associated with the Kelvin wave transported the stratospheric ozone into the troposphere.

\section{CONCLUSION}

We have conducted an observation with the ozone DIAL in Indonesia in June 1995 to investigate the

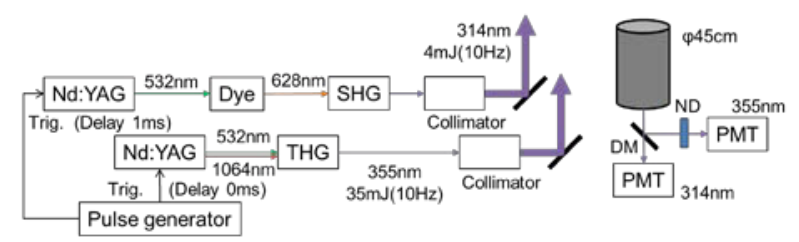

Fig. 1 Block diagram of the ozone DIAL system.

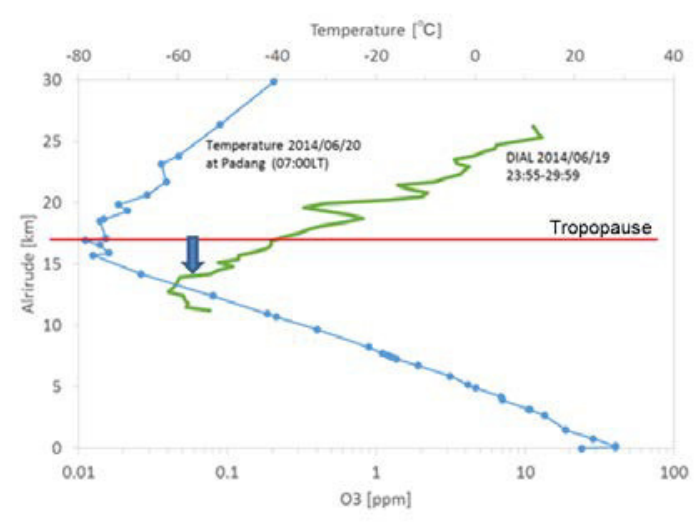

Fig.2 The ozone concentration profile and radiosonde temperature profile at Padang.

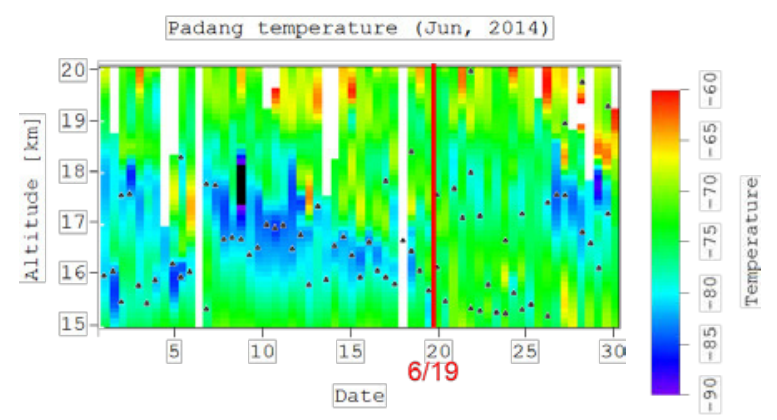

Fig. 3 Variations of vertical distribution of atmospheric temperature at Padang from June 1 to June 30, 2014. The tropopause height is indicated by asterisks $(*)$.

phenomenon of ozone enhancement in the tropical upper troposphere. A large ozone enhancement in the upper troposphere was observed. The O3 DIAL with high temporal resolution would clarify the relationship of the time variation of the ozone enhancement and the Kelvin wave. We will also contribute to the elucidation of the climate change by getting observational information about high resolution ozone density profiles, and the wavepropagation and material transportation using ozone as a tracer from the troposphere to the lower stratosphere over the equator.

\section{ACKNOWLEDGEMENT}

This work was financially supported by Grants-inAid for Scientific Research (No. 233401043).

\section{REFERENCES}

[1] Komala, N., S. Saraspriya, K. Kita, and T Ogawa, Atmos. Environ., 30, 1851-1856, 1996.

[2] Masatomo Fujiwara, Kazuyuki Kita, Toshihiro Ogawa, J. Geophys. Res., Vol. 103, No. D15, 19173-19182, 1998.

[4] C. Nagasawa, M. Abo, Y. Shibata, $23^{\text {rd }}$ International Laser Radar Conference, No.2O-8, pp.43 - 46, 2006.

[5] Gerard J. Megie, Gerard Ancellet, and Jacques Pelon, Appl. Opt. 24, 3454-3463, 1985.

[6] Masahisa Nakazato, Tomohiro Nagai, Tetsu Sakai, and Yasuo Hirose, Appl. Opt. 46, 22692279, 2007.

[7] M. Abo, C. Nagasawa, Y. Shibata, 26 ${ }^{\text {th }}$ International Laser Radar Conference, No.S1P44, 2012. 